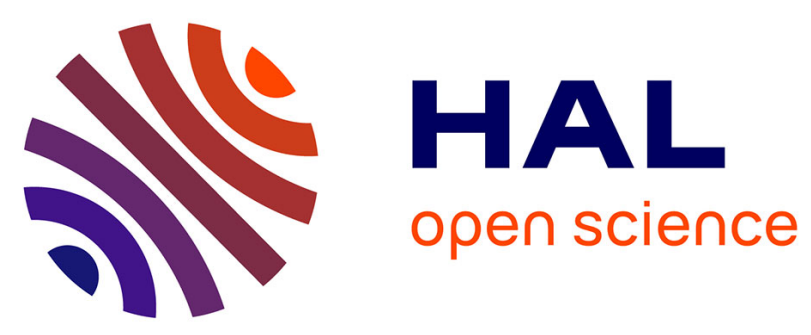

\title{
Pregnancies and obstetrical prognosis after oocyte donation in Turner Syndrome A multicentric study
}

Hélène Andre, Celine Pimentel, Segolene Veau, Mathilde Domin-Bernhard, Hélène Letur-Konirsch, Gérard Priou, Florence Eustache, Solène Vorilhon, Béatrice Delepine-Panisset, Patricia Fauque, et al.

\section{To cite this version:}

Hélène Andre, Celine Pimentel, Segolene Veau, Mathilde Domin-Bernhard, Hélène Letur-Konirsch, et al.. Pregnancies and obstetrical prognosis after oocyte donation in Turner Syndrome A multicentric study. European Journal of Obstetrics \& Gynecology and Reproductive Biology, 2019, 238, pp.73-77. 10.1016/j.ejogrb.2019.05.012 . hal-02153621

\section{HAL Id: hal-02153621 \\ https://hal-univ-rennes1.archives-ouvertes.fr/hal-02153621}

Submitted on 1 Jul 2019

HAL is a multi-disciplinary open access archive for the deposit and dissemination of scientific research documents, whether they are published or not. The documents may come from teaching and research institutions in France or abroad, or from public or private research centers.
L'archive ouverte pluridisciplinaire HAL, est destinée au dépôt et à la diffusion de documents scientifiques de niveau recherche, publiés ou non, émanant des établissements d'enseignement et de recherche français ou étrangers, des laboratoires publics ou privés. 
Title:

Pregnancies and obstetrical prognosis after oocyte donation in Turner Syndrome : A multicentric study

Hélène ANDRE ${ }^{1}$, Céline PIMENTEL ${ }^{1}$, Ségolène VEAU ${ }^{1}$, Mathilde DOMIN-BERNHARD ${ }^{1}$, Hélène LETUR-KONIRSCH ${ }^{2}$,Gérard PRIOU $^{3}$, Florence EUSTACHE ${ }^{4}$, Solène VORILHON $^{5}$, Béatrice DELEPINE-PANISSET ${ }^{6}$, Patricia FAUQUE ${ }^{7}$, Florence SCHEFFLER $^{8}$, Annie BENHAIM ${ }^{9}$, Oxana BLAGOSKLONOV ${ }^{10}$, Isabelle KOSCINSKI ${ }^{11}$, Célia RAVEL ${ }^{1,12}$

1-Univ Rennes, CHU, Centre d'AMP- CECOS, 16 Boulevard de Bulgarie, 35000 Rennes

2- Centre de Fertilité, Institut Mutualiste Montsouris, 42, boulevard Jourdan 75014 Paris

3-Clinique de la Sagesse, 4 Place Saint Guénolé-CS 44345, 35043 Rennes

4-CECOS Jean Verdier, AP-HP, 93000 Bondy. France

5-CHU Clermont-Ferrand, CGU Estaing, AMP, CECOS, 1 Place Aubrac, 63000 Clermont Ferrand, France

6-Biologie de la Reproduction - CECOS Champagne-Ardenne Pôle de Biologie Médicale et Pathologie 47 rue Cognacq-Jay, CHU , 51092 REIMS CEDEX

7-CHU Dijon Bourgogne, Laboratoire de Biologie de la Reproduction, 14 rue Gaffarel, F-21000 Dijon, France

8-CECOS Picardie CHU 80054 Amiens Cedex

9-Service de Biologie de la Reproduction Pôle de Biologie, CHU Côte de Nacre EA 2608 «OERECA», Esplanade de la Paix Université Caen Normandie

10- CECOS Franche-Comté, Service de Biologie de la Reproduction-Cryobiologie, CHRU Jean Minjoz Boulevard Fleming 25030 Besançon

11- CHRU de Nancy, INSERM U954 - Université de Lorraine ; Service de Biologie de la Reproduction-CECOS, Maternité, 10 rue du Dr Heydenreich, 54000 Nancy, France.

12- Univ Rennes, INSERM UMR1085- 9 av du Pr Léon Bernard- 35000 Rennes, IRSET, Rennes, France

\section{ABSTRACT}


Introduction : Turner syndrome is one of the most frequent chromosomal abnormalities in women, with a prevalence estimated to be 1 of 2500 live birth. Pregnancy in women with Turner syndrome is known to be at high risk, whether it is spontaneous or after oocyte donation, because of miscarriages and potential cardio-vascular complications which can be life-threatening. All of these patients should therefore be screened with a comprehensive cardio-vascular assessment before pregnancy, and have a close follow-up during and after pregnancy.

Patients and methods : It is a retrospective study, conducted in 10 of the 27 French oocyte donation centers between 2012 and 2016, on all the patients presenting with Turner syndrome included in an oocyte donation program.

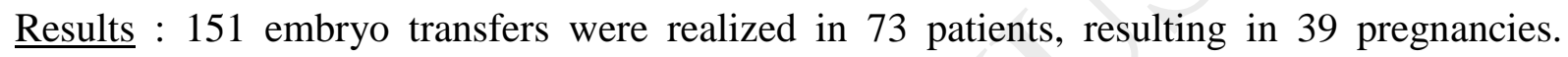
Among these pregnancies, 24 children were born healthy, 11 spontaneous miscarriages, 3 voluntary abortions, 1 extra-uterine pregnancy and 1 maternal death from non-cardio-vascular origin occurred. Pregnancies were complicated by gravid arterial hypertension in $28.2 \%$ of cases, preeclampsia in $10.3 \%$ of cases, and gestational diabetes in $7.7 \%$ of cases.

Conclusion : This study bring out obstetrical complications of the same magnitude than the ones described in the literature. Lead over a period of 4 years, in 10 French oocyte donation centers, it doesn't reveal any cardio-vascular complications, conversely to other studies published before French and American recommendations. This study reinforces the usefulness of specific recommendations for the care of these particular patients.

\section{INTRODUCTION}

Turner syndrome was first described in 1938 by Henry Turner, an American endocrinologist [1]. This congenital disorder is the main cause of hypergonadotropic hypogonadism in women. The most common features are a short stature and a premature ovarian failure from 
gonadic dysgenesis. Various morbidities can be associated, especially cardio-vascular and immune diseases. Apart from morbidity, mortality is also increased, as shown by a British and a Danish studies [2,3].

Turner syndrome is one of the most frequent chromosomal abnormalities, with a prevalence of 1 live born girl in 2500 [4]. It is due to the absence or structural abnormality of one of the $\mathrm{X}$ chromosome, with various degrees of mosaicism. Mosaicism attenuates the phenotype of Turner syndrome, especially the anthropometric data and the cardio-vascular morbidities [5,6]. Diagnosis of mosaic forms is established 8 years after the monosomic ones [7].

In Turner syndrome, migration and differentiation of germ cells seem to be done normally at the beginning of gestation, but their number significantly decreases in the middle of the pregnancy, probably by an apoptotic mechanism [8]. The decrease in the number of follicles could be due to an haplo-insufficiency of genes of the X chromosome which play a role in the ovarian maintenance [9].

Spontaneous puberty seems to appear in 10 to $20 \%$ of the patients with Turner syndrome, but less than $5 \%$ of these patients have spontaneous periods $[10,11]$. Spontaneous pregnancy can occur in 2 to $5 \%$ of cases, especially when the syndrome is associated with a high degree of mosaicism [12-14].

The ovarian reserve of these patients being low, it would be illusive to hope for good results after In Vitro Fertilization with their own oocytes. Therefore, patients who don't have spontaneous pregnancies can turn towards oocyte donation, which has permitted sensible improvement of their fertility. Oocyte donation is practiced in France since 1984. In 2007, $65 \%$ of women who benefited from this technique had a premature ovarian failure. Among them, $18,6 \%$ had a Turner syndrome [15].

However, procreation in a context of Turner syndrome is at high risk. Obstetrical prognosis is less good, with more miscarriages, hypertensive disorders, gestational diabetes and premature delivery. Moreover, the most worrying complications are cardio-vascular, because potentially life-threatening. Indeed, Turner syndrome is associated with congenital heart defects in 30 to $50 \%$ of cases. The most common defects are bicuspid aortic valve, coarctation of the aorta and aortic root dilatation, which can lead to aortic dissection [16-18].

This is why French and American scientific societies edited in 2009 and 2012 specific recommendations for the screening of these patients, before, during and after pregnancy $[19,20]$. These recommendations were following the death of two patients with Turner syndrome who had been pregnant thanks to oocyte donation. European recommendations 
were also updated in 2017 [19]. We aimed to evaluate the impact of these recommendations on the management of Turner Syndrome patients in oocyte donation.

\section{PATIENTS AND METHODS}

Study : It was a multicenter, observational, retrospective study, driven in 10 of the 26 French centers practicing oocyte donation between 2012 and 2016. These centers were retrospectively asked for the results of embryo transfers after oocyte donation done for Turner patients. The aims of the study were to evaluate the success rates of oocyte donation in patients with Turner syndrome (pregnancy and live birth rates) and the obstetrical complications, since the publication of recommendations.

Patients : Patients included were 18 to 43 years old, presented a Turner syndrome, and had benefited from at least one embryo transfer after oocyte donation. The diagnosis of Turner syndrome was based on a cytogenetic analysis.

Oocyte donation : The oocytes of the donor were collected by a trans-vaginal puncture after ovarian stimulation and triggering of ovulation. The mature ones (whether they were fresh or frozen) were injected with sperm of the of the male partner of the infertile couple. Recipients received an endometrial preparation with oral or transdermal estradiol and micronized vaginal progesterone. After controlling the endometrial thickness, the embryos obtained were transferred one by one in the uterus of the recipient. The supernumerary embryos were frozen for a subsequent transfer. Recipients all benefited from a complete screening, following the recommendations.

Obstetrical outcomes : Absence of pregnancy was defined as a negative hCG level 11 days after embryo transfer. Biochemical pregnancy was defined as a positive hCG level without gestational bag during ultrasonography examination. Clinical pregnancy was defined as the presence of a gestational bag. Miscarriage was defined as the expulsion of an intrauterine pregnancy. Extra uterine pregnancy was defined as a pregnancy implanted outside the uterine cavity. Fetal death was defined as a spontaneous stopping of the cardiac activity after 14 weeks of pregnancy

Pregnancy-induced hypertension was defined as new onset of hypertension of more than 140 $\mathrm{mm} \mathrm{Hg}$ systolic and/or more than $90 \mathrm{~mm} \mathrm{Hg}$ diastolic, after 20 weeks of pregnancy. Preeclampsia was defined as pregnancy induced hypertension associated with proteinuria > $300 \mathrm{mg} / 24 \mathrm{~h}$. Gestational diabetes was diagnosed by measuring fasting glucose in the first trimester of pregnancy, or after an OMS test (75g of glucose) between 24 and 28 weeks of pregnancy. 
$\underline{\text { Statistical analysis }}$ : All data were analyzed using Excel ${ }^{\circledR}$ and XIStat ${ }^{\circledR}$. Data are expressed as mean and percentages. Comparisons between groups were performed using Mann-Whitney and $\chi 2$ tests. A $P$ value $<0.05$ was considered statistically significant.

\section{RESULTS}

Studied population

73 patients were included. These patients benefited from 151 embryo transfers. Characteristics of the patients are described in table 1.

The mean age during the first embryo transfer was $32.5 \pm 4$ years old. Among them, $67.1 \%$ had a normal BMI, $25.5 \%$ were overweight and $7.1 \%$ were obese. The mean BMI was 23.69 $\pm 3.78 \mathrm{~kg} / \mathrm{m}^{2}$.

Oocyte donation

Among the 151 embryo transferred, 112 did not result in pregnancy (74.2\%), 39 resulted in a clinical pregnancy ( $25.8 \%$ of transfers and $53.4 \%$ of patients).

The flow chart of the studied population is described in figure 1.

Among these 39 clinical pregnancies :

- 11 resulted in a miscarriage (28.2\% of pregnancies)

- 1 was an extra uterine pregnancy ( $2.6 \%$ of pregnancies)

- 23 resulted in a live birth (59\% of pregnancies and $15.2 \%$ of transfers) of 25 newborns. 2 of these pregnancies were twin ones

$\underline{\text { Obstetrical issues }}$

Among the live births, the mean term of delivery was 38 weeks and 4 days of amenorrhea.

One maternal death happened at 21 weeks of amenorrhea, after hospitalization for status epilepticus. This patient had a heart ultrasonography before pregnancy which found out a moderate aortic root dilatation which was not a contraindication of pregnancy.

Another pregnancy ended with a premature delivery at 23 weeks and 2 days of amenorrhea. It was complicated by a severe pregnancy induced hypertension, with thrombotic microangiopathy and the aggravation of a preexisting renal failure.

One of the twin pregnancies was complicated with a severe preeclampsia which required a pregnancy interruption at 18 weeks of amenorrhea. Another pregnancy interruption was performed at 18 weeks of amenorrhea because of the presence of an hygroma coli at the ultrasonography examination. Finally, a third pregnancy interruption was performed on a male fetus, with a karyotype $46, \mathrm{XY}$ who presented a malformative association of the caudal pole (OEIS syndrome : omphalocele-exstrophy-imperforate anus-spinal defects). 
Furthermore, 11 patients suffered from pregnancy-induced hypertension $(28.2 \%$ of pregnancies). Among them, 4 suffered from preeclampsia $(10.3 \%) .3$ pregnancies were complicated by gestational diabetes $(7.7 \%)$. There was no case of aortic dissection, HELLP syndrome or eclampsia.

\section{Characteristics of the patients according pregnancy}

The Mann Whitney test did not found a significant statistical difference between the group who succeeded in having a pregnancy and the group who did not, according to the age $(\mathrm{p}=$ $0.74)$ and to the BMI $(\mathrm{p}=0.73)$. A khi2 test was performed to study the relationship between karyotype and the chances of obtaining a pregnancy. There was no significant difference between the two groups. These results are described in table 2.

\section{DISCUSSION}

Here we described a cohort of 73 patients with Turner syndrome, in whom we retrospectively studied oocyte donation outcomes. The aim of this study was to evaluate the pregnancy rates and the evolution of obstetrical complications, after the publication of national recommendations. The clinical pregnancy rate was $53.4 \%$ of patients.

The prevalence of pregnancies in this multicenter French cohort was $25.8 \%$ of embryo transfers. However, because of an important number of miscarriages, the rate of ongoing pregnancy falls to $15.2 \%$ of embryo transfers.

Bodri et al., in a study driven in Spain and published in 2005, reported an ongoing pregnancy rate of $30 \%$ of transfers. This elevated rate can be explained by a median number of transferred embryos of two [21]. Khatsgir et al., found an ongoing pregnancy rate of $19.1 \%$ without any influence of age or chromosomal abnormalities [22]. Karnis et al., in 2003, reported an ongoing pregnancy rate of $64.1 \%$ and suggested that there could be a bias due to the answers to their survey [16].

Regarding the pregnancy loss, the miscarriages rate in our study was $28.2 \%$ of pregnancies (7.3\% of transfers). Khatsgir et al. reported in 1997 a miscarriage rate of $50 \%$ of embryo transfers [22], whereas Karnis et al obtained low levels (6.4\%), still with the hypothesis of a response bias [16]. Bryman et al., in a study on 482 patients, concluded that the miscarriage rate was significantly lower in patients with Turner syndrome who had obtained a pregnancy with donor oocytes $(26 \%)$ than patients who had obtained a pregnancy with their own oocytes $(45 \%)$. This brings out the hypothesis of lower oocyte quality in Turner syndrome [23]. Moreover, whether pregnancies are spontaneous or obtained by Assisted Reproductive Technologies, the miscarriage rates remain higher than in the French general population 
(15\%). Some studies raised the hypothesis of abnormalities of endometrial receptivity inherent to the absence of some X-linked genes [24], associated to a small uterine volume and a reduced thickness of the endometrium [25]. Another explanation proposed by Abir et al. would be a high prevalence of auto-immune diseases in these patients [26].

Furthermore, pregnancies in patients with Turner's syndrome are at high risk for complications, especially cardiovascular ones. In our study, we found a rate of pregnancyinduced hypertension of $28.2 \%$ of pregnancies, and a preeclampsia rate of $10.3 \%$, without HELLP syndrome. Hagman et al. studied 106 patients with Turner syndrome and pregnant after egg donation. Their rates of hypertension were $35 \%$, and $20.5 \%$ of pregnancies were complicated by preeclampsia [27]. Alvaro Mercadal et al. had found a preeclampsia rate of $40 \%$ in 10 pregnancies obtained after oocytes donation [28]. Chevallier et al. studied 82 pregnancies after egg donation. The pregnancy rate was $17.1 \%$ and the preeclampsia rate 22 $\%$ [29]. Bernard et al., in a study of 480 patients with Turner's syndrome and spontaneously pregnant, found rates of hypertension and preeclampsia of $13.3 \%$ and $6.7 \%$, respectively [14]. Thus, it appears that post-donation pregnancies are statistically more complicated than spontaneous pregnancies in patients with Turner syndrome. To explain this difference, several hypotheses can be mentioned. First of all, the patients who succeed in obtaining a spontaneous pregnancy are those who have a less severe phenotype, and therefore less cardiovascular pathologies. In addition, these women are probably younger than those who use egg donation, because of the difficulty of this journey. In our study, the average age at first embryo transfer was 32.5 years. It was 32 years old in the Hagman's study [27] and 30.5 years old in Bernard's study [14]. Moreover, although pregnancies are spontaneous, women with Turner syndrome are more at risk of pregnancy-induced hypertensive diseases than the general population. This suggests that there is a risk associated with the syndrome itself. We can mention cardio-vascular or kidney diseases that predispose to hypertension. It has also been shown that patients with premature ovarian failure may present anti-zona pellucida and anti-granulosa cell autoantibodies. This could lead to abnormalities of dialogue between the trophoblastic cells and the endometrium, generating hypertensive pathologies [30]. Finally, independently of Turner syndrome, there is a risk of hypertensive pathologies inherent in oocyte donation. In an article published in 2017, Tarlatzi et al. compared 144 pregnancies obtained after oocyte donation to 144 pregnancies obtained after IVF or IVF-ICSI, in patients who did not have Turner syndrome. The former were associated with a significantly higher risk of pregnancy-induced hypertension and preeclampsia [31]. Indeed, the donor is immunologically foreign to the mother, which could lead to an inadequate immune response 
between the mother and the fetus and lead to hypertensive pathologies related to a reduced trophoblastic invasion [32-34]. There is also an endothelial dysfunction resulting from an imbalance between pro and anti-angiogenic factors [35].

In addition to cardiovascular complications, the risk of liver disease or gestational diabetes is high. However, we did not identify any liver dysfunction. Among the 39 cases studied, 3 pregnancies were complicated by gestational diabetes ( $7.7 \%$ of pregnancies). This result seems to be in agreement with the literature. In the Bryman et al. study, $5.3 \%$ of patients had gestational diabetes (23), whereas Hagman et al. reported a gestational diabetes rate of $9.4 \%$ (27). Finally, the maternal mortality rate in our study is $2.6 \%$, with one patient dying after status epilepticus. This death did not follow cardiovascular complications, such as those described in the literature.

The limitations of our study come from a limited number of patients, Turner syndrome being a rare pathology, which do not lead systematically leading to egg donation. Furthermore, oocyte donation in France is often a long process, with an expectation that can last several years. Thus, it is possible that a significant number of couples whose wife is suffering from Turner syndrome give up the start of the procedures in France and benefit from egg donations abroad. In addition, only 10 of the 27 centers participating at that time in oocyte donation responded to our questionnaire. It is therefore a non-exhaustive investigation, although multicentric. There may be a response bias. If centers that did not respond are those with lower success rates or higher cardiovascular complications, this could lead to an underestimation of those complications or even mortality.

\section{CONCLUSION}

Pregnancies in women with Turner's syndrome are at high risk, whether obtained with their own oocytes or with those from a donor. These complications can be cardiovascular, and potentially life-threatening. The purpose of this study was to re-evaluate the pregnancy rates and obstetric complications in patients with Turner syndrome who achieved pregnancy after oocyte donation. This reassessment follows the publication of French and American recommendations in 2009 and 2012, after the demonstration of a mortality of cardiovascular cause increased in these patients during pregnancy. We found rates of pregnancy, miscarriage and obstetric complications similar to those described so far in the literature, and did not demonstrate cardio-vascular death. Our study reinforces the usefulness of specific recommendations for the care of these particular patients. 


\section{REFERENCES}

1. Turner H. Classic pages in obstetrics and gynecology by. A syndrome of infantilism, congenital webbed neck, and cubitus valgus. Endocrinology, vol. 23, pp. 566-574, 1938. Am J Obstet Gynecol 1972;113:279.

2. Swerdlow AJ, Hermon C, Jacobs PA, Alberman E, Beral V, Daker M, et al. Mortality and cancer incidence in persons with numerical sex chromosome abnormalities: a cohort study. Ann Hum Genet 2001;65:177-88.

3. Stochholm K, Juul S, Juel K, Naeraa RW, Højbjerg Gravholt C. Prevalence, Incidence, Diagnostic Delay, and Mortality in Turner Syndrome. J Clin Endocrinol Metab 2006;91:3897 -902 .

4. Cabrol S. Le syndrome de Turner. Ann Endocrinol 2008;68:2-9.

5. Bucerzan S, Miclea D, Popp R, Alkhzouz C, Lazea C, Pop IV, et al. Clinical and genetic characteristics in a group of 45 patients with Turner syndrome (monocentric study). Ther Clin Risk Manag 2017;13:613-22.

6. Cameron-Pimblett A, La Rosa C, King TFJ, Davies MC, Conway GS. The Turner Syndrome Life Course Project: Karyotype-phenotype analyses across the lifespan. Clin Endocrinol (Oxf). 2017;87:532-538.

7. El-Mansoury M, Barrenäs M-L, Bryman I, Hanson C, Larsson C, Wilhelmsen L, et al. Chromosomal mosaicism mitigates stigmata and cardiovascular risk factors in Turner syndrome. Clin Endocrinol (Oxf) 2007;66:744-51.

8. Modi DN, Sane S, Bhartiya D. Accelerated germ cell apoptosis in sex chromosome aneuploid fetal human gonads. Mol Hum Reprod 2003;9:219-25. 
9. Carrel L, Willard HF. X-inactivation profile reveals extensive variability in X-linked gene expression in females. Nature 2005;434:400-4.

10. Delbaere A, Englert Y. Syndrome de Turner et don d'ovocytes. Gynécologie Obstétrique Fertil 2002;30:970-8.

11. Hovatta O, Hreinsson J, Fridström M, Borgström B. Fertility and pregnancy aspects in Turner syndrome. Int Congr Ser 2006;1298:185-9.

12. Ayuso MC, Bello MJ, Benitez J, Sanchez-Cascos A, Mendoza G. Two fertile Turner women in a family. Clin Genet 1984;26:591-6.

13. Birkebaek N, Crüger D, Hansen J, Nielsen J, Bruun-Petersen G. Fertility and pregnancy outcome in Danish women with Turner syndrome. Clin Genet 2002;61:35-9.

14. Bernard V, Donadille B, Zenaty D, Courtillot C, Salenave S, Brac de la Perrière A, et al. Spontaneous fertility and pregnancy outcomes amongst 480 women with Turner syndrome. Hum Reprod 2016;31:782-8.

15. Letur H. État des pratiques du don d'ovocytes en France et en Europe. J Gynécologie Obstétrique Biol Reprod 2008;36:727-37.

16. Karnis MF, Zimon AE, Lalwani SI, Timmreck LS, Klipstein S, Reindollar RH. Risk of death in pregnancy achieved through oocyte donation in patients with Turner syndrome: a national survey. Fertil Steril 2003;80:498-501.

17. Matura LA, Ho VB, Rosing DR, Bondy CA. Aortic Dilatation and Dissection in Turner Syndrome. Circulation 2007;116:1663-70.

18. Bondy CA. Congenital Cardiovascular Disease in Turner Syndrome. Congenit Heart Dis $2008 ; 3: 2-15$. 
19. Collège national des gynécologues et obstetriciens francais - Recommandations pour la pratique clinique - Syndrome de Turner et grossesse . 2009 [cité 1 juill 2017]. http://www.cngof.asso.fr/D_TELE/RPC_Turner_et_gro_090723.pdf

20. Practice Committee of the American Society for Reproductive Medicine. Increased maternal cardiovascular mortality associated with pregnancy in women with Turner syndrome. Fertil Steril 2012;97:282-4.

21. Bodri D, Vernaeve V, Figueras F, Vidal R, Guillén JJ, Coll O. Oocyte donation in patients with Turner's syndrome: a successful technique but with an accompanying high risk of hypertensive disorders during pregnancy. Hum Reprod 2006;21:829-32.

22. Khastgir G, Abdalla H, Thomas A, Korea L, Latarche L, Studd J. Oocyte donation in Turner's syndrome: an analysis of the factors affecting the outcome. Hum Reprod 1997;12:279-85.

23. Bryman I, Sylvén L, Berntorp K, Innala E, Bergström I, Hanson C, et al. Pregnancy rate and outcome in Swedish women with Turner syndrome. Fertil Steril 2011;95:2507-10.

24. Yaron Y, Ochshorn Y, Amit A, Yovel I, Kogosowki A, Lessing JB. Patients with Turner's syndrome may have an inherent endometrial abnormality affecting receptivity in oocyte donation. Fertil Steril 1996;65:1249-52.

25. O’Donnell RL, Warner P, Lee RJ, Walker J, Bath LE, Kelnar CJ, et al. Physiological sex steroid replacement in premature ovarian failure: randomized crossover trial of effect on uterine volume, endometrial thickness and blood flow, compared with a standard regimen. Hum Reprod 2012;27:1130-8.

26. Abir R, Fisch B, Nahum R, Orvieto R, Nitke S, Ben Rafael Z. Turner's syndrome and fertility: current status and possible putative prospects. Hum Reprod Update 2001;7:603-10. 
27. Hagman A, Loft A, Wennerholm U-B, Pinborg A, Bergh C, Aittomäki K, et al. Obstetric and neonatal outcome after oocyte donation in 106 women with Turner syndrome: a Nordic cohort study. Hum Reprod 2013;28:1598-609.

28. Mercadal BA, Imbert R, Demeestere I, Englert Y, Delbaere A. Pregnancy outcome after oocyte donation in patients with Turner's syndrome and partial X monosomy. Hum Reprod $2011 ; 26: 2061-8$

29. Chevalier N, Letur H, Lelannou D, Ohl J, Cornet D, Chalas-Boissonnas C, et al. MaternoFetal Cardiovascular Complications in Turner Syndrome after Oocyte Donation: Insufficient Prepregnancy Screening and Pregnancy Follow-Up Are Associated with Poor Outcome. J Clin Endocrinol Metab 2011;96:E260-7.

30. Kelkar RL, Meherji PK, Kadam SS, Gupta SK, Nandedkar TD. Circulating autoantibodies against the zona pellucida and thyroid microsomal antigen in women with premature ovarian failure. J Reprod Immunol 2005;66:53-67.

31. Tarlatzi TB, Imbert R, Mercadal BA, Demeestere I, Venetis CA, Englert Y, et al. Does oocyte donation compared with autologous oocyte IVF pregnancies have a higher risk of preeclampsia? Reprod Biomed Online 2017;34:11-8.

32. Salha O, Sharma V, Dada T, Nugent D, Rutherford AJ, Tomlinson AJ, et al. The influence of donated gametes on the incidence of hypertensive disorders of pregnancy. Hum Reprod $1999 ; 14: 2268-73$

33. Ohl J, Koscinski I, Schindler L, Teletin M, Murer M, Galland I. Pathologies des grossesses issues de don d'ovocytes. Gynécologie Obstétrique Fertil 2012;40:511-6.

34. Savasi VM, Mandia L, Laoreti A, Cetin I. Maternal and fetal outcomes in oocyte donation pregnancies. Hum Reprod Update 2016;22:620-33.

35. Levine RJ, Maynard SE, Qian C, Lim K-H, England LJ, Yu KF, et al. Circulating Angiogenic Factors and the Risk of Preeclampsia. N Engl J Med 2004;350:672-83. 
Figure 1 - Flow chart of the study

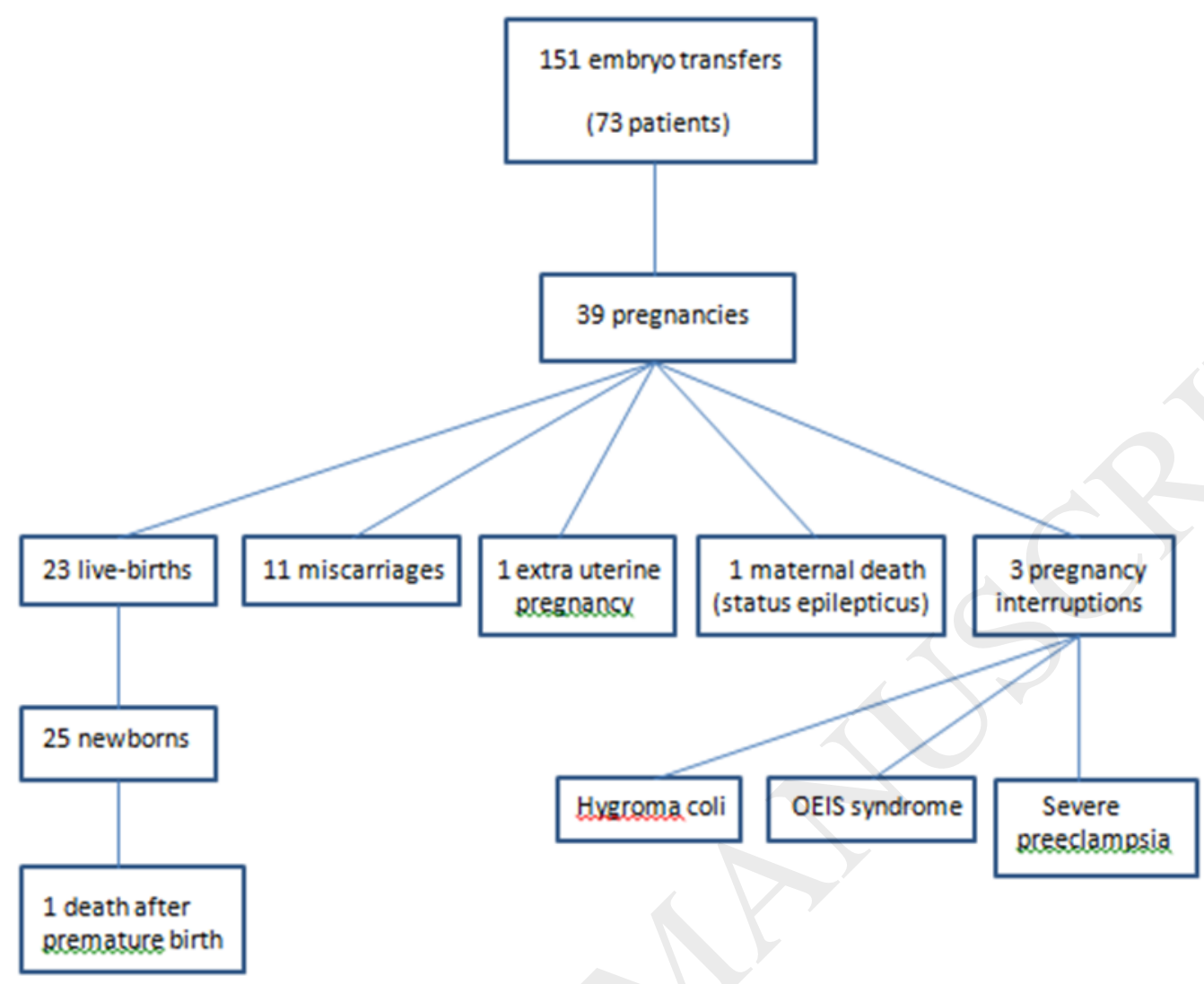

OEIS syndrome : omphalocele-exstrophy-imperforate anus-spinal defect 
Table 1 - Characteristics of the patients $(n=73)$

\begin{tabular}{|c|c|}
\hline & $n=73$ \\
\hline Age (years) & 32,5 \\
\hline BMI (kg/m2) & 23,69 \\
\hline Normal (BMI 18.5-25) & $67,10 \%$ \\
\hline Overweight (BMI 25-30) & $25,70 \%$ \\
\hline Obese $(\mathrm{BMI}>30)$ & $7,10 \%$ \\
\hline \multicolumn{2}{|l|}{ Karyotype } \\
\hline $45, X$ & $38,3 \%(n=28)$ \\
\hline $45, X / 46, X X$ & $11 \%(n=8)$ \\
\hline $46, X, \operatorname{del}(X)$ & $8,2 \%(n=6)$ \\
\hline $45, X / 46, X, i(X)$ & $4,1 \%(n=3)$ \\
\hline $46, X, i(X)$ & $4,1 \%(n=3)$ \\
\hline $45, X / 47, X X X$ & $4,1 \%(n=3)$ \\
\hline $45, X / 46, X, \operatorname{der}(Y)$ & $4,1 \%(n=3)$ \\
\hline $45, X / 46, X X / 47, X X X$ & $2,7 \%(n=2)$ \\
\hline $46, X, \operatorname{der}(X)$ & $2,7 \%(n=2)$ \\
\hline $45, X / 46, X, \operatorname{der}(X)$ & $1,4 \%(n=1)$ \\
\hline Not available & $19,2 \%(n=14)$ \\
\hline
\end{tabular}


Table 2 - Characteristics of the patients according pregnancy

\begin{tabular}{|rccc|}
\hline & Pregnancy & No pregnancy & p \\
\hline Age & 30,81 & 32,19 & 0,74 \\
\hline BMI & 23,6 & 20,9 & 0,73 \\
\hline Karyotype & & & 0,43 \\
\hline $45, X / 46, X X$ & $5(12,8)$ & $45(40,2)$ & \\
\hline Others & $13(33,3)$ & $6(5,4)$ & \\
\hline & $6(15,4)$ & $37(33)$ & \\
\hline
\end{tabular}

